\title{
Financial Technology Literacy (Fintech) in Ponorogo: Perception and Attitude
}

\author{
Yutisa Tri Cahyani ${ }^{1}$, Lukman Santoso ${ }^{2}$, Tunjung Genarsih ${ }^{3}$ \\ Faculty of Islamic Economics and Business IAIN Ponorogo $0^{1,3}$ \\ Faculty of Sharia IAIN Ponorogo ${ }^{2}$ \\ \{yutisatricahyani92@gmail.com ${ }^{1}$, cak_luk@iainponorogo.ac.id ${ }^{2}$, ginargin28@gmail.com ${ }^{3}$ \}
}

\begin{abstract}
In today's digital era, information technology is developing so rapidly. The same is the case with the development of the technology-based financial industry or what is known as fintech. The potential for digital finance in Indonesia is huge and it is important to develop it. The fast pace of innovation has resulted in various changes in all aspects of life in the financial sector. At this time, consumers can easily access a variety of information and features of electronic services. So that the presence of this fintech, can change people's behavior in conducting financial transactions. This study aims to determine the perceptions and attitudes of the people of Ponorogo towards financial technology literacy (fintech). This study uses a descriptive quantitative approach with a sample of 92 respondents. The data obtained by means of observation, filling out questionnaires, and documentation. This study uses multiple linear regression analysis techniques. The results of this study are that there is a significant influence on perceptions of financial technology, there is a significant influence on attitudes towards financial technology and the simultaneous influence of perceptions and attitudes towards financial technology.
\end{abstract}

Keywords: Perception; Attitude; Financial Technology Literacy

\section{Introduction}

The phenomenon of starup began since the increasingly stretched information technology. The period 1990-2000 was the first period of development of many information technology companies, although in the period of the year in the 1970s-1980s, technology companies such as Apple and Microsoft were already established as pioneers [1]. In today's digital age, information technology is growing very rapidly. This is a form ofinnovation that successfullytransforms the existing system or market, thereby affecting human behavior and expectations. At this time, consumers canaccessa variety of electronic service information and featureseasily. Ease and speed in information technology are the hallmarks of the digital age.

The latest technological developments in Indonesia are financial technology or Financial Technology (FinTech). Financial technology industry (fintech) is one of the methods of financial services that began to be popular in today's digital era. Digital payments are one of the most 
developed fintechindustry sectorsinIndonesia. This sector is then most expected by the government and the public to encourage an increase in the number of people who have access to financial services. The potential of the digital economy in Indonesia is huge and important to develop. The rapid pace of innovation resulted in various changes in all aspects of life in finance and including the payment system, where the changes were getting shorter which resulted in $a$ narrower response time for authorities to make policies. Fintechdevelopment has changed people's behavior in conducting financial transactions. The ease of fintech transactions not only changes people's behavior, but also contributes to the increase of financial inclusion and the national economy. Therefore, we hope that the regulation that will be issued by the Financial Services Authority will further support the progress of the fintech-based financial industry and the interests of consumers are increasingly protected [8].

Globally, the Fintech industry continues to grow rapidly. Evident from the emergence of startup companies in this field as well as the amount of global investment in it. Especially in Indonesia, this business is growing so rapidly that it attracts the attention of all business people in Indonesia [6]. The reason FinTech in Indonesia attractsindustry i attention, namely Ease in financial process, supporting technological developments, inspired by previous businesses, more flexible than conventional businesses, the use of Software technology and Big Data as part of risk analysis.

\subsection{Problem Formulation}

Based on the background that the authors described in this study, the problem formulation is as follows:

a. Is there any influence of perception on financial technology literacy?

b. Is there an influence on financial technology literacy?

c. Is there a shared influence of perception and attitude towards financial technology literacy?

\subsection{Financial Technology}

Financial Tecnologi is a technology that becomes an intermediary and liaison between the general public and the financial sector. In general, financial technology is related to the use of technology as a solution to financial problems. The presence of fintech is one of the solutions to traditional financial industry problems that cannot serve the community as a whole. Traditional financial industry has limitations because it has strict rules in serving people in certain areas.

The National Digital Research Centre in Dublin (2014) defines Financial Technology as an innovation in financial services by leveraging the development of information technology. Accordingto the International Trade Administration (2016), Financial Techology is a financial and skills "revolution" in the merger of financial services with information technology that has improved the quality of financial services, and created financial stability. [10] FinTech alsofocusedon using technology to provide financialsolutions. Specifically, FinTech is defined as a digital technology application for financial intermediation problems [3][11].

Generally, Indonesian people who do not understand fintech. Fintech is a combination of financial system with digital technology. In the process, technology is changing the way people view the conventional financial system to be more modern. Currently fintech users can do all transaction processes only in the palm of their hands through the gadget. The development of many fintech startup companies makes it easier for consumers to provide fast and efficient services [12]. 
The presence of fintech can make Indonesians become cashless society or at least minimize the use of banknotes. Long-distance transactions that used to be common for a long time can now be completed in just seconds without knowing the distance.

\section{Perception and Attitude Theory}

There are several understandings of consumer behavior expressed by experts including according to Mangkunegara, "Consumer behavior is actions carried out by individuals, groups or organizations related to the decision-making process in obtaining, using economical goods or services that can be influenced by the environment" [14]. While winardi's definitionof consumer behavior is: "Behavior directed at people in planning, buying and using economic goods and services" [15].

From some of the above definitions, the author can draw the conclusion that what is meant by consumer behavior is a number of real actions of individuals (Consumers) that are influenced by internal and external factors that direct them to assess, select, obtain and use the goods and services they want.

\subsection{Perception}

In general, perception is a process that makes a person to choose, organize and interpret the received stimuli into a meaningful and complete picture of his world. Perception is essentially a cognitive process experienced by everyone in understanding information about their environment, is a unique interpretation of the situation. Perception indicates the existence of a view of each person towards something whether condition, circumstance or atmosphere. [16], [17].

\subsection{Attitude}

Attitude is a disposition to respond positively or negatively to certain behaviors. An attitude is a reaction to a relatively stagnant object or situation that is accompanied by a certain feeling and provides the basis for the person to make a response or behaviorin a certain way that he or she chooses. Sunaryo's attitude is the tendency of individuals to act in the form of closed responses to stimulus or certain objects. Where in terms of attitude, it can be divided into accepting, responding, appreciating, and responsible [19]. An evaluation of a person's concept is a concept, in which evaluation can be created by both affective and cognitive systems. Attitude implies an action that suits a person's condition or circumstances [20].

\subsection{Hypothesis}

Hypothesis is a temporary answer to the formulation of research problems, where the problem formulation is expressed in the form of question sentences. Hypotheses are temporary answers because they are only based on relevant theories, not yet based onempirical facts obtained throughdatacollection. The hypotheses in this study are:

a. Perception has a significant influence on financial technology literacy in Ponorogo

b. Attitudes have a significant influence on financial technology literacy in Ponorogo

c. Perceptions and Attitudes simultaneously affect financial technology literacy in Ponorogo 


\section{Research Methods}

This research is a descriptive quantitative research. According to Sugiyono[22] quantitative research is a research method based on the philosophy of positivism, used to research on certain populations or samples, sampling techniques are generally done randomly, data collection using research instruments, data analysis is quantitative / statistical with the aim to test the hypothesis that has been determined. While descriptive research according to Suprapto [23], is a study of the status, opinions of individual groups, devices of conditions and procedures, a system of thought or events in order to create a description or description systematically and analytically that can be used to solve actual problems today. The data used in this study is primary data, namely data obtained from the analysis of respondent questionnaire data [24] .

\section{a) Population and Sample}

The population in this study is the entire community aged 18 years and above in Ponorogo Regency. Sampling technique used is simple random sampling that is a simple random sampling by giving equal opportunities to each member of the population.

\section{b) Data Collection Methods And Operational Definitions}

The data collection technique used is a questionnaire that is distributed online for all threevariables. This research variable consists of two free variables, namely perception () and attitude () and one bound variable, namely financial technology literacy (). $X_{1} X_{2} \hat{Y}$

\section{c) Data Analysis Techniques}

Data processing in this study used SPSS 25 program with multiple regression analysis to see the simultaneous influence of free variables on bound variables. The multiple regression models used are as follows:

$$
\hat{Y}=\alpha+\beta_{1} X_{1}+\beta_{2} X_{2}+e
$$

Based on the regression model above can be explained is the literacy of financial services, is a perception, is an attitude, is a coefficient of regression and is a constant. This regression model is then tested assumptions to see if the regression model has accuracy in estimation, is unbiased and consistent. As for seeing the influence of partially used test $t$. The significance level is $5 \%$, then the test criteria are as follows: if the value of $t$ calculates more than the value of the table t then the variable has a significant effect and if the value of $t$ calculates less than the value of the table $t$ then the variable has no significant effect. Next to see the influence simultaneously used test $\mathrm{F}$ with test criteria if the value of $\mathrm{F}$ calculate greater than $\mathrm{F}$ table then the variables have simultaneous effect. $\hat{Y} X_{1} X_{2} \beta \alpha$

\section{d) Reliability Test and Validity Test}


The research instrument was developed using Kotler theory for variable perception and attitude, with Likert measurement scale. Test question items on questionnaires using validity and reliability tests. The validity test used is the Pearson Product Pearson correlation. This analysis correlates each item's score with the total score. The criteria used to measure whether

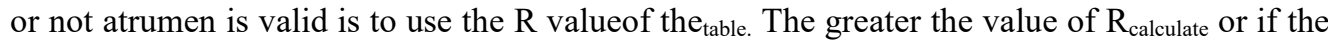
value of $R_{\text {calculate }}>\mathrm{R}$ table then the statement item is valid and vice versa. While the reliability test used is cronbach alpha reliability test. Kuesioner is said to be reliabel if it has a Cronbach Alpha value of more than 0.60 . Reliability tests can be performed if the instrument has been tested for validity.

\section{Results And Discussions}

Angket Validity and Reliability Test Results

\begin{tabular}{lllll}
\multicolumn{5}{c}{ Table 1. Validity Test Results } \\
\hline Variable & ITEM & Rhitung & Rtabel & Decision \\
\hline Perception & X1.1 & 0,777 & 0,207 & Valid \\
& X1.2 & 0,836 & 0,207 & Valid \\
X1.3 & 0,837 & 0,207 & Valid \\
X1.4 & 0,862 & 0,207 & Valid \\
& X1.5 & 0,906 & 0,207 & Valid \\
X1.6 & 0,831 & 0,207 & Valid \\
& X1.7 & 0,886 & 0,207 & Valid \\
& X1.8 & 0,812 & 0,207 & Valid \\
Xariable & ITEM & Rhitung & Rtabel & Decision \\
Attitude & X2.1 & 0,798 & 0,207 & Valid \\
& X2.2 & 0,761 & 0,207 & Valid \\
& X2.3 & 0,795 & 0,207 & Valid \\
& X2.4 & 0,746 & 0,207 & Valid \\
& X2.5 & 0,565 & 0,207 & Valid \\
X2.6 & 0,740 & 0,207 & Valid \\
Financial Technology Literacy & Y1 & 0,853 & 0,207 & Valid \\
& Y2 & 0,794 & 0,207 & Valid \\
& Y3 & 0,833 & 0,207 & Valid \\
& Y4 & 0,801 & 0,207 & Valid \\
& Y5 & 0,841 & 0,207 & Valid \\
\hline
\end{tabular}

Table 2. Reliability Test Results

Reliability Statistics

\begin{tabular}{|r|r|}
\hline $\begin{array}{c}\text { Cronbach's } \\
\text { Alpha }\end{array}$ & N of Items \\
\hline .956 & 21 \\
\hline
\end{tabular}

Based on quadrant reliability test results obtained Cronbach's Alpha value of 0.956 greater than 0.6 so that it can be concluded that the item of reliable questionnaire.

\subsection{Research Results}


Table 3. Multiple Regression Analysis

Coefficients $^{\mathrm{a}}$

\begin{tabular}{|c|c|c|c|c|c|c|}
\hline \multirow[b]{2}{*}{ Mod } & & \multicolumn{2}{|c|}{ Unstandardized Coefficients } & $\begin{array}{l}\text { Standardized } \\
\text { Coefficients }\end{array}$ & \multirow[b]{2}{*}{$\mathrm{t}$} & \multirow[b]{2}{*}{ Sig. } \\
\hline & & B & Std. Error & Beta & & \\
\hline \multirow[t]{3}{*}{1} & (Constant) & 2.165 & 1.217 & & 1.779 & .079 \\
\hline & PERSEPSI & .191 & .055 & .355 & 3.465 & .001 \\
\hline & SIKAP & .383 & .077 & .505 & 4.937 & .000 \\
\hline
\end{tabular}

a. Dependent Variable: LITERASI

Based on the table above obtained regression equation:

$\widehat{Y}=2.165+0.191 X_{1}+0.383 X_{2}$

The regression equation can be interpreted as follows:

a. The value $\mathrm{a}=2,165$ constant numbers which means that if the variable perception and attitude is 0 then the amount of financial technology literacy variable is 2,165 .

b. The value $b_{1}=0.191$ is the coefficient of regression of the perception variable, meaning that every increase of one point / unit of perception variables then the variable of financial technology literacy will increase by 0.191 on the condition that other variables are of constant value. It can also be interpreted that the perception has a positive effect on financial technology literacy, so that if the perception increases then financial technology literacy will also increase.

c. The value $b_{2}=0.383$ is the regression coefficient of attitude variables, meaning that each increase of one pound / unit of attitude variables then the variable of financial technology alliteration will increase by 0.383 . It can also be interpreted that the attitude has a positive effect on financial technology literacy, so that if the attitude increases then financial technology literacy will also increase

Table 4. Test $\mathrm{t}$

Coefficients $^{\mathrm{a}}$

\begin{tabular}{|c|c|c|c|c|c|c|}
\hline \multirow[b]{2}{*}{ Mod } & & \multicolumn{2}{|c|}{ Unstandardized Coefficients } & \multirow{2}{*}{$\begin{array}{c}\begin{array}{c}\text { Standardized } \\
\text { Coefficients }\end{array} \\
\text { Beta }\end{array}$} & \multirow[b]{2}{*}{$\mathrm{t}$} & \multirow[b]{2}{*}{ Sig. } \\
\hline & & B & Std. Error & & & \\
\hline \multirow[t]{3}{*}{1} & (Constant) & 2.165 & 1.217 & & 1.779 & .079 \\
\hline & PERSEPSI & .191 & .055 & .355 & 3.465 & .001 \\
\hline & SIKAP & .383 & .077 & .505 & 4.937 & .000 \\
\hline
\end{tabular}

a. Dependent Variable: LITERASI

In this study, the number of respondents used as many as 92 . So it can be determined the value $_{\text {e }}$ of $t$ table is 1.6696 and the level of significance is $5 \%$. Based on the table above obtained $t_{\text {calculated }}$ value is 3465 for perception variable and also obtained significance value of 0.001 which means less than 0.05 . So it can be concluded that because the value of $t_{\text {calculate }}$ is greater than the table $t_{v a l u e}$ and the significance value is less than 0.05 then the perception variable has a significant effect on the variables of financial technology literacy.

Based on the table above can also be known that the value of $t_{\text {calculate }}$ is 4937 for the attitude variable and also obtained a significance value of 0.000 which means less than 0.05 . So it can 
be concluded that attitude variables also have a significant effect on financial technology literacy variables.

Table 5. Test $\mathrm{F}$

ANOVA $^{\mathrm{b}}$

\begin{tabular}{|ll|r|r|r|r|r|}
\hline \multicolumn{1}{|c|}{} & \multicolumn{1}{c|}{$\begin{array}{c}\text { Sum of } \\
\text { Squares }\end{array}$} & df & Mean Square & \multicolumn{1}{c|}{$\mathrm{F}$} & \multicolumn{1}{c|}{ Sig. } \\
\hline 1 & Regression & 794.373 & 2 & 397.187 & 89.696 & $.000^{\mathrm{a}}$ \\
& Residual & 394.105 & 89 & 4.428 & & \\
& Total & 1188.478 & 91 & & & \\
\hline
\end{tabular}

a. Predictors: (Constant), SIKAP, PERSEPSI

b. Dependent Variable: LITERASI

The $\mathrm{F}$ test is used to see if two free variables namely perception and attitudes simultaneously affect financial technology literacy. To see the lack of influence can use the value of calculated $\mathrm{F}_{\text {as }}$ well as the value of significance. Based on many respondents have obtained that the value ${ }_{\text {of }}$ $\mathrm{F}$ table is 3.10. In the table above the calculated $\mathrm{F}_{\text {value }}$ of 89.696 has a value greater than the table F. While the significance value of 0.000 is less than 0.05 . So it can be concluded that perceptions and attitudes simultaneously have a significant effect on financial technology literacy.

\subsection{Coefficient of Determination}

This analysis is used to find out how much contribution an Independent variable contributes or is free (perception and attitude) to dependent or bound variables (financial technology literacy) indicated by percentage. The results of the determination coefficient can be seen in the following table:

Table 6. The Results of the Determination Coefficient

Model Summary

\begin{tabular}{|l|l|r|r|r|}
\hline $\begin{array}{l}\text { Mode } \\
\mid\end{array}$ & $\mathrm{R}$ & $\mathrm{R}$ Square & $\begin{array}{c}\text { Adjusted R } \\
\text { Square }\end{array}$ & $\begin{array}{c}\text { Std. Error of } \\
\text { the Estimate }\end{array}$ \\
\hline 1 & $.818^{\mathrm{a}}$ & .668 & .661 & 2.104 \\
\hline
\end{tabular}

a. Predictors: (Constant), SIKAP, PERSEPSI

Based on the table above the coefficient of determination obtained a positive value from $\mathrm{R}^{2}$ (adjusted R Square ) of 0.661 which means that the influence given independent variables namely perception and attitude to dependent variables namely financial technologyliteracyof 0.661 or $66.1 \%$, meaning the remaining $33.9 \%$ of financial technology literacy is affected by other variables outside the research model.

\subsection{Discussion}

a. The Influence of Perception on Financial Technology Literacy. Based on the results of the above research ${ }_{\text {obtained }}$ the value of $t$ calculate is 3465 for the variable perception and obtained a significance value of 0.001 which means less than 0.05 . So it can be concluded that because the value of $t_{\text {calculate }}$ is greater than the table $t_{\text {value }}$ and the significance value is less than 0.05 then the perception variable has a significant effect on the variables of financial technology 
literacy. It can be meant that the people of Ponorogo are aware that financial technology (fintech)is neededtoday, especially during this pandemic. In addition, financial technology is also useful for the lives of ponorogo people. In the research also proved that ponorogo people can easily learn and use financial technology.

b. The Influence of Attitudes on Financial Technology Literacy. Based on the results of the study above it is known that the value of $t$ calculate is 4937 for attitude variables and also obtained a significance value of 0.000 which means less than 0.05 . So it can be concluded that attitude variables also have a significant effect on financial technology literacy variables. This means that the people of Ponorogo already use financial technology (fintech)for the benefit ofpayment (Payment),funding (Funding),financing (Financing,) banking(DigitalBanking)and also market place to shop online.

c. The Influence of Perception and Attitude to Financial Technology Literacy. From the results of the study, Ftabel by 3.10. In the table above the value of Fhitung is 89.696 has a value greater than Fbel. While the significance value of 0.000 is less than 0.05 . So it can be concluded that perceptions and attitudes simultaneously have a significant effect on financial technology literacy. This means that the people of Ponorogo know and understand well about financial technology (fintech) and also follow the development of financial technology products(fintech). In addition, the people of Ponorogo also understand well the types of fintech-based financial services.

\section{Conclusion}

After conducting data processing and discussion, it can be concluded as follows: First, perception has a significant effect on financial technology literacy in Ponorogo with a significance value of 0.001 and $t_{\text {count }}$ of 3.465 . Second, attitudes have a significant effect on financial technology literacy in Ponorogo with a significance of 0.000 and a $t_{\text {count }}$ of 4,937. Third, perception and attitudes have a simultaneous effect on financial technology literacy in Ponorogo with a significance of 0.000 and $F$ counts at 89,696.

\section{References}

[1] D. Wijayanto, Legal in startup business. Metagraf, 2018.

[2] G. Buchak, G. Matvos, T. Piskorski, and A. Seru, "Fintech, regulatory arbitrage, and the rise of shadow banks," Journal of Financial Economics, vol. 130, no. 3, pp. 453-483, 2018.

[3] A. M. Aji, H. Harisah, and S. G. Mukri, "Revitalization of Fintech Era 4.0 in the Development of Islamic Microfinance Institutions (IMFs)," Al-Iqtishad: Jurnal Ilmu Ekonomi Syariah, vol. 12, no. 1, 2020.

[4] B. Wibowo and I. Krisnadi, "Analysis of Fintech Regulation in Building The Economy in Indonesia," Journal of Master of Electrical Engineering, Mercu BuanaUniversity, vol. 1, no. 1, pp. 1-9, 2016.

[5] E. W. Prastyaningtyas, "Impact of Digital Economy for Indonesia's Economy," in National Seminar on Management, Economics, Accounting, 2019, vol. 1, no. 1, pp. $103-$ 108.

[6] S. Winasis, "Digital Transformation in the Indonesian Banking Industry: Impact on Employee Work Stress," IQTISHADIA: Jurnal Ekonomi \& Banking Syariah, vol. 7, no. 1, pp. 55-64, 2020. 
[7] A. S. Dz, "Financial Inclusion of Sharia Banking Based on Digital-Banking: Optimization and Challenges," Al-Amwal: Journal of Sharia Economics and Banking,vol. 10, no. 1, pp. 63-80, 2018.

[8] M.M. Tampi, "Measuring the Progressivity of Financial Technology (Fintech) in Business Law in Indonesia," Era Hukum-Jurnal Ilmiah Ilmu Hukum,vol. 16, no. 2, 2019.

[9] S. Adiningsih, Digital Based Economic Transformation in Indonesia. Jakarta: Gramedia Pustaka Utama, 2019.

[10] R. Fahlefi, "Sharia Financial Inclusion Through Fintech Innovation in Philanthropy Sector," PROCEEDING IAIN Batusangkar,vol. 4, no. 1, pp. 205-212, 2019.

[11] L.M. Aliyah and Nurdin, "The Influence of Technology-Based Financial Services (Fintech) on Financial Literacyof Dago Atas Community, Bandung," in ManagementProceedings, Bandung, Feb. 2019, vol. 5.

[12] C.M. Mulasiwi and K. O. Julialevi, "Optimization of Financial Technology (Fintech) to Improve Financial Literacy and Inclusion of Purwokerto Medium Enterprises," Performance: Journal of Personnel, Financial, Operations, Marketing and Information Systems, vol. 27, no. 01, pp. 12-20, 2020.

[13] E. D. Setyaningsih and L. Vanda, "SWOT Financial Technology Analysis on The Quality of Banking Services in the Disruptive Era," SNIT 2018,vol. 1, no. 1, pp. 60-65, 2018.

[14] A. P. Mangkunegara, Human Resources Management Company. Bandung: PT. Teenager Rosdakarya, 2002.

[15] Winardi and Suparwarman, Consumer Behavior. Publisher PT. Earth Script. Jakarta, Jakarta. Jakarta: Bumi Aksara, 2003.

[16] F. K. Sari, N. Safitri, and W. Anggraini, "Perceptions, Attitudes and Interests of Halal Tourism in the Special Region of Yogyakarta," Ihtifaz: Journal of Islamic Economics, Finance, and Banking,vol. 2, no. 2, pp. 137-156, 2019.

[17] D. W. Arner, J. Barberis, and R. P. Buckley, "The evolution of Fintech: A new postcrisis paradigm," Geo. J. Int'l L. , vol. 47, p. 1271, 2015.

[18] P. Gomber, J.-A. Koch, and M. Siering, "Digital Finance and FinTech: current research and future research directions," Journal of Business Economics, vol. 87, no. 5, pp. 537580, 2017.

[19] S. Sunaryo, "Influence of Organizational Change, Organizational Culture and Work Behavior on Employee Performance at PT Sisirau Medan," Scientific Journal of Management and Business, vol. 18, no. 1, pp. 101-114, 2017.

[20] I. P. S. Putra, H. Ananingtiyas, D. R. Sari, A. S. Dewi, and M. Silvy, "The influence of financial literacy, experienced regret, and risk tolerance on the selection of investment types," Journal of Business and Banking,vol. 5, no. 2, pp. 271-282, 2016.

[21] Sugiyono, Mixed Methods. Bandung: Alfabeta, 2013.

[22] Sugiyono, Quantitative, Qualitative and $R \& D$ Research Method. Bandung: Alfabeta, 2006.

[23] Suprapto, Research Methodology of Educational Sciences and Social Sciences. Jakarta: Fun Book, 2013.

[24] T. Genarsih, Economic and Business Statistics (Easy Practice with SPSS). Yogyakarta: Zahir Publishing, 2020. 